\title{
Psychosocial risks and stress as predictors of burnout in junior doctors performing emergency guards
}

\author{
María Fernández-Prada', Joaquín González-Cabrera ${ }^{2}$, Concepción Iribar-Ibabe \\ and José María Peinado3,4 \\ ${ }^{1}$ Department of Preventive Medicine and Public Health, Hospital Universitario Central de Asturias, Oviedo; ${ }^{2}$ Department of Education Psychology \\ and Psychobiology, Universidad Internacional de La Rioja, Logroño; ${ }^{3}$ Department of Biochemistry and Molecular Biology III and Immunology; \\ ${ }^{4}$ Instituto de Neurociencias Federico Olóriz, Universidad de Granada, Granada, Spain
}

\begin{abstract}
Objective: The objective of the study was to study the stress, the psychosocial risks associated to the job and the burnout, in a group of junior doctors working at the emergency ward; and to analyze what of those variables could predict and are better related with burnout. Methods: A cross-sectional study, with a sample of 42 junior doctors which are on duty in the emergency ward of the University Hospital San Cecilio, Granada (Spain). The Spanish adapted version of the perceived stress scale was used to evaluate stress, the Maslach Burnout Inventory (MBI) to evaluate the professional burnout and the adapted and scaled questionnaire for the self-evaluation of psychosocial risks at work (CopSoQ-ISTAS21). Results: About 78\% of the junior doctors are in the unfavorable or intermediate range for all CopSoQ-ISTAS21 dimensions, being particularly relevant that $90 \%$ of them display unfavorable score in psychological demands (PD). In addition, MBI results show that $45 \%$ of our population presents high emotional exhaustion simultaneously to high depersonalization. ISTAS21 PD dimensions $(\beta=0.393$; $p<0.003)$ and stress scores $(\beta=0.451 ; p<0.001)$ significantly predict emotional exhaustion $(r 2=0.443)$. Finally, $38 \%$ of junior doctors experienced a threat/aggression during their work in the emergency ward urgencies. Conclusion: Junior doctors develop its professional activity under adverse circumstances probably due to the high psychosocial risk associated to the job. $P D$ are suggested as the main predicting factor of burnout. These results indicate the need for psychological and structural interventions to improve the professional performance of junior doctors at the emergency ward.
\end{abstract}

KEY WORDS: Burnout. Psychosocial risk. Stress. Junior doctors. Emergency guards.

\section{Introduction}

In Spain, a large number of medicine, nursing, pharmacy, biology, chemistry, and other disciplines' graduates who have passed the exam to gain access to a specialized healthcare training post join the National Health System every year. Concretely, in the 2014-2015 convocation, 35,320 graduates took the exam for one of the 7527 openings offered by the Ministry of Health, Social Services and Equity ${ }^{1}$. In the medical area, there were an estimated 30,051 junior doctors (residents) in Spain in 2014, out of which about 7400 (24.6\%) corresponded to family and community medicine and, therefore, they have to stay on duty at the emergency department (ED)2.

In general terms, junior doctors comprise a group with the broad theoretical knowledge that joins a demanding and competitive working market for the $1^{\text {st }}$ time. The workload and responsibility conferred to this medical character can sometimes be disproportionate with regard to his/her experience and skills. In this sense, these physicians represent a group that is potentially vulnerable to problems of stress, burnout and psychosocial risks, especially within settings where the need for an immediate response is inherent to the job ${ }^{3}$. An important part of the research has

\section{Correspondence:}


preponderantly focused on the assessment of burnout $^{4}$ without evaluating other constructs such as stress, health-related quality of life ${ }^{5}$ or psychosocial risks associated with the job, as well as their possible prediction or the relationship between them. Those who have looked more deeply into the subject have associated sociodemographic variables such as the number of times staying on duty with higher levels of burnout ${ }^{6}$. However, it becomes necessary to delve into personal and professional factors that may help to explain burnout?.

On the other hand, psychosocial risks and stress are becoming one of the priority lines of action in health, in such a way that the European Agency for Safety and Health at Work focused on these subjects in 2014 and 2015 during the European Weeks for Safety and Health at Work ${ }^{8}$. Nevertheless, so far there are only a few publications made on medical personnel, let alone with physician trainees. Globally addressing medical personnel, González-Cabrera et al. ${ }^{9}$ have brought to light the relationship between psychosocial risks and stress in emergency physicians. These authors observe that this work is characterized by high psychological demands (PD), an intermediate control over the job and unfavorable social support (SS), and it is, therefore, an ideal culture broth for the appearance of work stress. In addition, the serious conditions of the patients attending these services, as well as staying on duty in shifts of up to $24 \mathrm{~h}$, might be factors contributing to the development of this phenomenon. Other authors have also established relationships between these psychological dimensions in other groups, such as corrections officers and teaching personnel ${ }^{10,11}$.

In addition, the psychological and physical deleterious effects shown by people undergoing high levels of stress negatively affect health and behavioral operability. In turn, stress is closely related to the amount of psychosocial resources that are possessed or thought to be possessed to cope with the requirements of certain demanding situations ${ }^{12}$.

The purposes of this work are to assess the psychological situation of junior doctors with regard to stress, the psychosocial risks associated with the job and burnout, as well as to analyze which variables are associated and better predict burnout.

\section{Methods}

The participants were 42 junior doctors from the Hospital Universitario San Cecilio (Granada, Spain),
32 females and 10 males with a mean age of $26.38 \pm$ 1.71 years. Each one had a mean of $68.31 \pm$ 17.71 monthly hours at the ED (with a range of $40-140$ hours/month). 32 belonged to medical, 5 to surgical and 5 to medical-surgical branches. There were 25 $1^{\text {st }}$ year (R1) and $172^{\text {nd }}$ year (R2) residents. With regard to the organizational structure, the junior doctors had a morning workday (8:00 to 15:00 h), which could be prolonged up to 8:00-h next day staying "on duty." The study was conducted within the period comprised between the months of February and April 2012. The inclusion criteria were being a junior doctor and staying at least 40 monthly hours on duty at the ED. The only exclusion criterion was having experienced a traumatic psychological event within the past 6 months. A non-probabilistic, incidental sampling was carried out. During the study period, 75 junior doctors (41 R1 and $34 \mathrm{R} 2$ ) had to stay on-duty at the ED. Of the target population, $52 \%$ did participate.

Sociodemographic variables such as gender, age, type of specialty, year of residency, number of hours staying on duty at the ED, threats/physical or verbal aggressions received, as well as other data, are shown in table 1.

Three validated and self-administered questionnaires have been employed (one of them has been assessed for the Spanish population):

- Spanish-adapted version of the perceived stress scale (PSS). The PSS original version consists of 14 items that evaluate the perception of control on the demands of the surroundings. An adapted and validated into Spanish version has been used $^{13}$.

- Questionnaire for self-assessment of psychosocial risks at work (CopSoQ-ISTAS21, short version 1.5$)^{14}$. It is designed to identify, measure and evaluate the exposure to 6 large dimensions of psychosocial risk for health at work: (a) PD, as the workload in relation to the time available to perform it and transfer of feelings at work; (b) double presence, i.e., the need to respond simultaneously to the demands of the job and domestic-family work; (c) control over the job (CJ), or margin of autonomy in the way to perform the job and the possibilities given to apply skills and knowledge; (d) SS and quality of leadership (SS), such as support from superiors or coworkers in the performance of work; (e) esteem (EST), personal recognition and respect obtained in relation to the effort made on the job; and ( $f$ ) insecurity about the future, understood as unwanted 
Table 1. Sociodemographic variables relative frequencies or arithmetic mean ( \pm standard deviation). Comparisons have been established for dependent samples $(n=42)$

\begin{tabular}{|c|c|c|c|c|}
\hline \multirow[b]{2}{*}{1} & \multirow[b]{2}{*}{ Have you suffered any physical/verbal aggression and/or threat from any patient? } & \multirow{2}{*}{$\begin{array}{l}\text { Frequencies } \\
\text { Yes }=16 \\
\text { No }=26\end{array}$} & \multicolumn{2}{|c|}{$\begin{array}{l}\text { Mean ( } \pm \text { standard } \\
\text { deviation) }\end{array}$} \\
\hline & & & & \\
\hline 2 & How many? & $\begin{array}{l}\text { Once }=7 \\
\text { Twice }=6 \\
\text { Three or more }=3\end{array}$ & & \\
\hline 3 & Did you file any legal complaint against the aggressor? & $\mathrm{No}=16$ & & \\
\hline 4 & Are you allowed by your department to take the day off after having stayed on duty? & $\begin{array}{l}\text { Yes }=39 \\
\text { No }=3\end{array}$ & & \\
\hline 5 & $\begin{array}{l}\text { The day after having stayed on duty, do you think on the patients you provided care to, } \\
\text { questioning yourself about the diagnosis/prescribed treatment? }\end{array}$ & & $3.54( \pm 1.15)$ & \\
\hline 6 & How often do you use to consult with your coworkers each time you are on duty? & & $3.97( \pm 0.80)$ & $\begin{array}{l}\mathrm{t}=1.159 \\
\mathrm{p}<0.253\end{array}$ \\
\hline 7 & How often do you use to consult with your superiors each time you are on duty? & & $3.42( \pm 0.96)$ & \\
\hline 8 & $\begin{array}{l}\text { How often do you perceive your doubts are adequately solved when asking a } \\
\text { coworker? }\end{array}$ & & $3.47( \pm 0.83)$ & $\begin{array}{l}\mathrm{t}=0.883 \\
\mathrm{p}<0.393\end{array}$ \\
\hline 9 & How often do you perceive your doubts are adequately solved when asking a superior? & & $3.31( \pm 0.96)$ & \\
\hline 10 & How often do you feel supported by a coworker in the face of a problem with a patient? & & $4.04( \pm 0.93)$ & $\begin{array}{l}t=7.051 \\
p<0.001\end{array}$ \\
\hline 11 & $\begin{array}{l}\text { How often do you feel supported by your superior in the face of a problem with a } \\
\text { patient? }\end{array}$ & & $2.83( \pm 0.88)$ & \\
\hline
\end{tabular}

From item 5-11, the questions adopt a Likert-type multiple-answer format of 5 alternatives within the "frequency" continuum. A 1-5 Likert scale was used, where 1 represents the lowest value, 3 an intermediate value, and 5 the highest value.

changes on working conditions or loss of job. Exposure levels can be qualitatively classified as unfavorable, intermediate or favorable. This criterion refers to the risk for psychosocial health originating in work organization.

- Spanish version of the Maslach Burnout Inventory $(M B I)^{15}$, which evaluates three dimensions: Emotional exhaustion (EE), depersonalization (DE), and personal accomplishment (PA). It consists of 22 items, each one of which is assessed with a $0-6$ point Likert-type scale. To obtain comparability in the results, the MBI total score has been obtained by adding only the EE and $\mathrm{DE}$ dimensions (with the PA scale being excluded) ${ }^{7}$.

Several meetings were held with the junior doctors, where the general lines of research were exposed, and the informative document and the informed consent form were provided. The residents were asked to fill the questionnaires in a single moment in time and the only instructions provided were to read the indications explained in the booklet of answers, and to answer specifically based on their experience accumulated at the ED, not at their department of origin.
Collaboration was voluntary, anonymous, and disinterested. The ethical procedure followed the standards of the Declaration of Helsinki. Each participant signed a written informed consent, which included the possibility to withdraw at any phase of the study. The study was approved by the Investigation Ethics Commission of the Granada Province.

Statistical analyses were performed by means of the SPSS 15.0 program (IBM $\left.{ }^{\odot}\right)$, and graphic representations with Sigmaplot 11.0 (Systat Software ${ }^{\odot}$ ). The following analyses were performed: (1) Sample normal distribution (Shapiro-Wilks statistic) and variance homogeneity (Levene's test) verification; (2) frequency analysis, measures of central tendency and dispersion of the measure; (3) calculation of the scores typified for all variables where comparisons or relations were established; (4) Student's t-test for independent and dependent samples; (5) Pearson's bivariate correlations; (6) analysis of variance (7) $\chi^{2}$ test; and (8) "stepwise" multiple linear regression using the $F$ probability for an input value of 0.15 and an output value of 0.20 . $p<0.05$ was considered to be significant. 


\section{Results}

Sociodemographic variables related to work at the ED are partially shown in table 1, with the fact standing out that $38 \%$ of surveyed students referred having experienced at least one aggression or threat. In addition, the preference of junior doctors to address their pairs rather than their superiors is appreciated, especially when they want to feel supported in decision-making $(p<0.001)$.

With regard to the scores obtained in PSS, our results show that 14 junior doctors (33.3\%) are above percentile 75 , which indicates that a relevant percentage has reduced control on the demands of their setting.

There are no significant differences between males and females $(t=-1.206 ; p<0.235)$ or between $R 1$ and $R 2(t=0.362 ; p<0.719)$. Neither are there differences between different types of specialty $\left(F_{2,39}=0.808 ; p<\right.$ 0.453 ), between those who have suffered or not an aggression or threat $(t=-0.748 ; p<0.450)$, or between those who choose to rest or not the day after having stayed on duty $(t=-0.385 ; p<0.702)$.

Fig. 1 depicts the percentage of junior doctors in the unfavorable/low, intermediate/medium and favorable/high categories for the six dimensions of the ISTAS21 questionnaire and all three MBI dimensions. It is important highlighting that $78 \%$ fall in the unfavorable or intermediate categories for all ISTAS21 dimensions. In addition, $45 \%$ had high EE and DE MBI scores simultaneously. There are no significant differences between males and females in none of ISTAS21 or MBI dimensions. The only differences found between $R 1$ and $R 2$ were in the PA scores $(t=-2.434$; $p<0.017)$. There were no differences according to the type of specialty, resting or not the days after having stayed on duty or having suffered or not an aggression or threat.

Mean values and standard deviations for $\mathrm{MBI}$ dimensions are: EE, $20.95 \pm 10.52 ; \mathrm{DE}, 7.33 \pm 5.76$; and $\mathrm{PA}, 37.76 \pm 5.69$.

Table 2 summarizes the relationship between the presence of burnout and different sociodemographic variables, as well as the values obtained after making comparisons using the $\chi^{2}$ test. PA according to the year of residency was the only significant comparison $\left(\chi^{2}=6.212 ; p<0.045\right)$.

As for variables that are related to and predict burnout, table 3 summarizes the partial correlations between PSS, MBI and ISTAS21 total scores controlled for age.
Table 4 summarizes the multiple linear regressions using ISTAS21 and PSS dimensions as predictors over the EE, DE, and PA criteria. Our results show that ISTAS21 PS and EST dimensions, together with PSS total score, are the best predictors of the MBI dimensions in our sample.

Finally, if we perform a linear regression using MBI total score as a criterion and the amount of hours at the ED as a predictor, we find that this is not a relevant variable to predict burnout $\left(r^{2}=0.034 ; \beta=-0.185\right.$; $t=-1.160 ; p<0.253)$.

\section{Discussion}

The present work has addressed in a novel form a study construct that is highly debated in the current literature. Empirical indicators have been obtained whereby to predict burnout levels in a sample of junior doctors who stay on duty at the ED. High PDs and high levels of stress are the best predictors both for EE and PA among novice physicians (Table 4). In addition, esteem significantly predicts PA. However, if a joint assessment of ISTAS21 different dimensions is made, especially of those directly related to Karasek and Theorell demand-control model ${ }^{16}$, we find results that are convergent with those reported for other medical professional groups, such as emergency doctors: high PDs, poor task control and reduced SS $^{9}$. These results seem to point at a structural problem of EDs ${ }^{17}$, which can be aggravated by a lack of technical and human means ${ }^{18}$.

It is possible for the high PDs that were found to be due to a deficit of clinical skills or to poor self-calibration of junior doctors' real skills and knowledge. In any case, it might be thought that residents are exposed to a series of working demands and contingencies for which they may not be adequately trained, which would explain why $90 \%$ of them had unfavorable scores (Fig. 1). The training received during the undergraduate period, and later for the national exam for admission to residency is eminently theoretical ${ }^{19,20}$. When residents join the hospital, they spontaneously refer important deficits on clinical, communication, exploratory, test interpretation, and organization (writing of reports, prescriptions, etc.) skills ${ }^{21}$.

In consequence, the discontinuity existing between the undergraduate period, preparation for the residency exam and the beginning of a specialty can put the residents in a psychosocial position of high vulnerability to stress and PDs. 


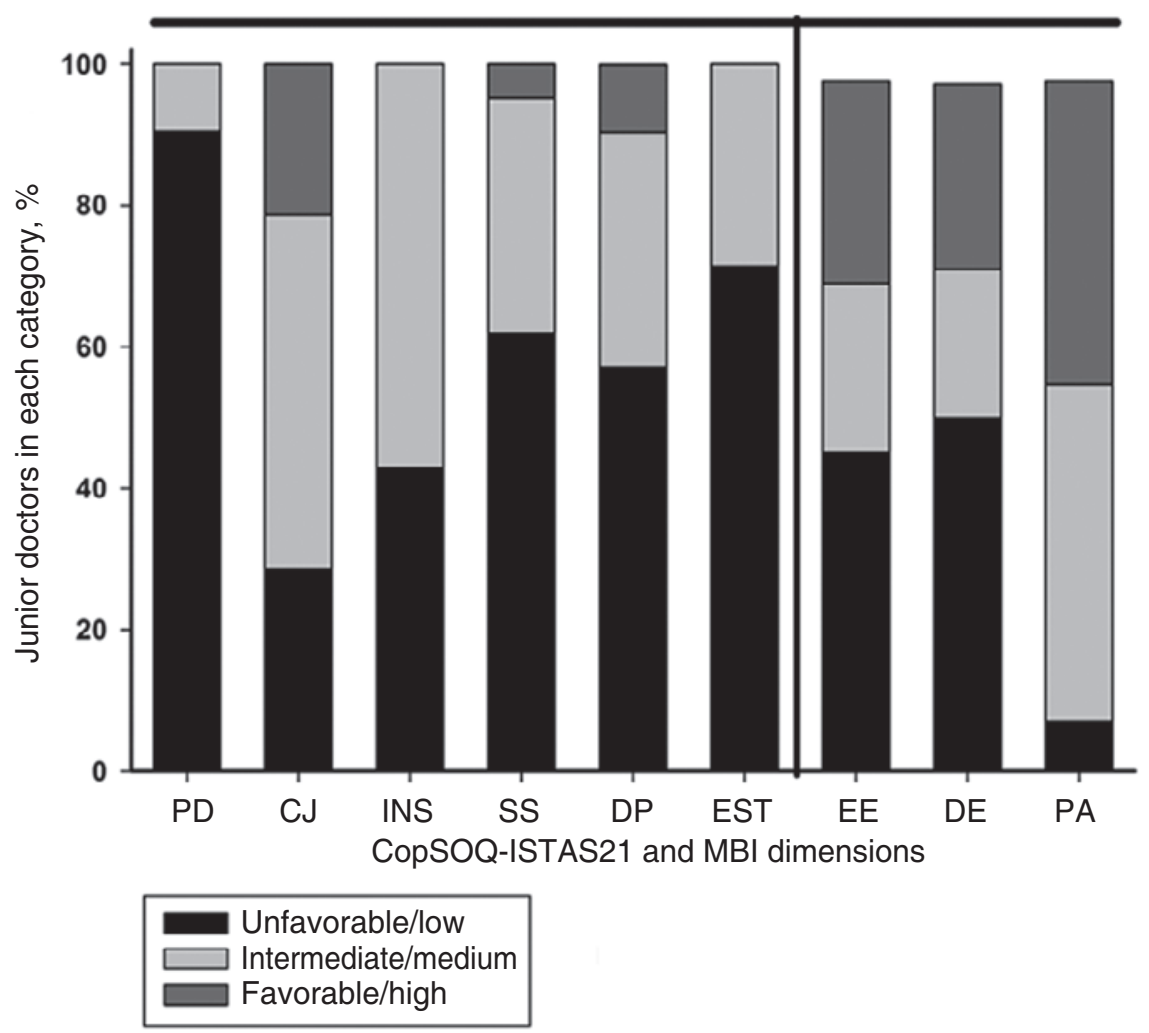

Figure 1. Percentage of junior doctors who are at a favorable/intermediate/unfavorable position in the CoPSOQ-ISTAS21 and MBI dimensions. CJ: control over the job; DE: depersonalization; DP: double presence; EE: emotional exhaustion; EST: personal esteem; INS: insecurity about the future; PA: personal achievements; PD: psychological demands; SS: social support.

Peer and superior figures SS is fundamental for adequate integration and stabilization of residents in EDs due to its modulating role with stress and PDs. That is why the results shown in table 1 are worrying, since they show the residents' preferences for consulting with their coworkers rather than with physicians, and when they consult them, the perception of solution offered by a peer or a superior is equal. Of note, residents feel significantly more supported by their peers than by staff physicians, which might explain part of the unfavorable SS many junior doctors refer perceiving (Fig. 1). These data are not consistent in the case when primary care physicians are surveyed about their job satisfaction and aspects of job improvement ${ }^{22}$.

In addition, the results reflect that a percentage lower than $40 \%$ of residents has intermediate or high levels of burnout. However, the lack of a consensus criterion about burnout and differences in the methodological possibilities hinder comparisons between studies $^{7,23}$. Mean values obtained in our sample for
$\mathrm{MBI}$ different dimensions are consistent with other studies $^{24}$.

Sociodemographic variables do not yield differences, since gender, year of residence, type of specialty, having suffered aggressions or threats and resting or not on the day after having stayed on duty show no differences for the MBI or ISTAS21 dimensions.

In this work, no relationship has been found between the number of hours staying on duty and burnout, although other authors have established $i^{6}{ }^{6}$. It should be mentioned that our residents have indicated a mean number of $68.31 \mathrm{~h}$ per month, which represents approximately 3 monthly times staying on duty. However, for some residents, the hours staying on duty with regard to their specialty should be added. In any case, it seems to be appreciated that burnout levels of healthcare professionals remain especially high, and pointing at other psychosocial variables that may help us to predict it is, therefore, necessary. This appreciation appears to be related to some works that have not described reductions in the degree of burnout in spite of the reduction of working hours ${ }^{25}$. 
Table 2. Relationship between the presence of burnout and different sociodemographic variables and $\chi^{2}$ comparisons $(n=42)$

\begin{tabular}{|c|c|c|c|c|c|c|c|c|c|}
\hline & & \multicolumn{4}{|c|}{ Emotional exhaustion } & \multicolumn{2}{|c|}{ Depersonalization } & \multicolumn{2}{|c|}{ Personal achievements } \\
\hline & & \multicolumn{2}{|c|}{ Males } & \multicolumn{2}{|c|}{ Females } & Males & Females & Males & Females \\
\hline \multicolumn{10}{|l|}{ Gender } \\
\hline \multicolumn{2}{|l|}{ Low } & \multicolumn{2}{|c|}{$5(11.9 \%)$} & \multicolumn{2}{|c|}{$15(35.7 \%)$} & $5(11.9 \%)$ & $17(40.5 \%)$ & $1(2.4 \%)$ & $3(7.1 \%)$ \\
\hline \multicolumn{2}{|c|}{ Intermediate } & \multicolumn{2}{|c|}{$2(4.8 \%)$} & \multicolumn{2}{|c|}{$8(19 \%)$} & $2(4.8 \%)$ & $7(16.7 \%)$ & $4(9.5 \%)$ & $16(38.1 \%)$ \\
\hline \multicolumn{2}{|l|}{ High } & \multicolumn{2}{|c|}{$3(7.1 \%)$} & \multicolumn{2}{|c|}{$9(21.4 \%)$} & $3(7.1 \%)$ & $8(19.0 \%)$ & $5(11.9 \%)$ & $13(31.0 \%)$ \\
\hline & & \multicolumn{4}{|c|}{$\left(\chi^{2}=0.108 ; p<0.947\right)$} & \multicolumn{2}{|c|}{$\left(\chi^{2}=0.098 ; p<0.952\right)$} & \multicolumn{2}{|c|}{$\left(\chi^{2}=0.654 ; p<0.718\right)$} \\
\hline \multicolumn{2}{|l|}{ Stays on duty } & \multicolumn{2}{|c|}{ No } & \multicolumn{2}{|l|}{ Yes } & No & Yes & No & Yes \\
\hline \multicolumn{2}{|l|}{ Low } & \multicolumn{2}{|c|}{$2(4.8 \%)$} & \multicolumn{2}{|c|}{$18(42.9 \%)$} & $2(4.8 \%)$ & $20(\%)$ & $0(0 \%)$ & $4(9.5 \%)$ \\
\hline \multicolumn{2}{|c|}{ Intermediate } & \multicolumn{2}{|c|}{$0(0 \%)$} & \multicolumn{2}{|c|}{$10(0 \%)$} & $1(2.4 \%)$ & $8(19 \%)$ & $2(4.8 \%)$ & $18(42.8 \%)$ \\
\hline \multicolumn{2}{|l|}{ High } & \multicolumn{2}{|c|}{$1(2.4 \%)$} & \multicolumn{2}{|c|}{$11(26.2 \%)$} & $0(0 \%)$ & $11(26.2 \%)$ & $1(2.4 \%)$ & $17(40.5 \%)$ \\
\hline & & \multicolumn{4}{|c|}{$\left(\chi^{2}=1.727 ; p<0.222\right)$} & \multicolumn{2}{|c|}{$\left(\chi^{2}=1.932 ; p<0.381\right)$} & \multicolumn{2}{|c|}{$\left(\chi^{2}=1.029 ; p<0.598\right)$} \\
\hline Year of resid & ency & & 21 & $\mathrm{R} 2$ & & $\mathrm{R} 1$ & R2 & $\mathrm{R} 1$ & R2 \\
\hline Low & & 11( & $6.8 \%)$ & $9(21.4 \%$ & & $14(33.3 \%)$ & $8(19 \%)$ & $3(7.1 \%)$ & $1(2.4 \%)$ \\
\hline Intermedia & & $6(1$ & $4.3 \%)$ & $4(9.5 \%$ & & $5(11.9 \%)$ & $4(9.5 \%)$ & $15(35.7 \%)$ & $5(11.9 \%)$ \\
\hline High & & & 19\%) & $4(9.5 \%$ & & $6(14.3 \%)$ & $4(11.9 \%)$ & $7(16.7 \%)$ & $11(26.2 \%)$ \\
\hline & & & $\left(\chi^{2}=0.426\right.$ & $0<0.407)$ & & $\left(\chi^{2}=0.326 ; p\right.$ & 0.849) & $\left(\chi^{2}=6.216 ; p\right.$ & $0.045)$ \\
\hline Specialty & Medical & Surgical & $\begin{array}{l}\text { Medical- } \\
\text { surgical }\end{array}$ & Medical & Surgical & $\begin{array}{l}\text { Medical- } \\
\text { surgical }\end{array}$ & Medical & Surgical & $\begin{array}{l}\text { Medical- } \\
\text { surgical }\end{array}$ \\
\hline Low & $16(38.1 \%)$ & $2(4.8 \%)$ & $2(4.8 \%)$ & 17 (40.5\%) & $3(7.4 \%)$ & $2(4.8 \%)$ & $4(9.5 \%)$ & $0(0 \%)$ & $0(0 \%)$ \\
\hline Intermediate & $9(21.4 \%)$ & $0(0 \%)$ & $1(2.4 \%)$ & 7 (16.7\%) & $1(2.4 \%)$ & $1(2.4 \%)$ & $12(28.6 \%)$ & 4 (9.5\%) & $4(9.5 \%)$ \\
\hline High & 7 (16.7\%) & $3(7.1 \%)$ & $2(4.8 \%)$ & $8(19 \%)$ & $1(2.4 \%)$ & $2(4.8 \%)$ & $16(38.1 \%)$ & 1 (2.4\%) & $1(2.4 \%)$ \\
\hline & $\left(\chi^{2}=\right.$ & $4.875 ; p<$ & $0.300)$ & & $\left(\chi^{2}=0.63\right.$ & $<0.959)$ & & $=7.698 ; p<$ & \\
\hline
\end{tabular}

R1: first-year resident; R2: second-year resident.

Table 3. Age-adjusted Pearson's partial correlations between PSS, MBI and ISTAS21 $(n=42)$

\begin{tabular}{|c|c|c|c|c|c|c|c|c|c|}
\hline & $\begin{array}{l}\text { Emotional } \\
\text { exhaustion }\end{array}$ & Depersonalization & $\begin{array}{c}\text { Personal } \\
\text { achievements }\end{array}$ & $\begin{array}{l}\text { Psychological } \\
\text { demands }\end{array}$ & $\begin{array}{l}\text { Control of } \\
\text { the job }\end{array}$ & $\begin{array}{l}\text { Social } \\
\text { support }\end{array}$ & $\begin{array}{l}\text { Personal } \\
\text { esteem }\end{array}$ & $\begin{array}{l}\text { Double I } \\
\text { presence }\end{array}$ & $\begin{array}{l}\text { Insecurity } \\
\text { of future }\end{array}$ \\
\hline PSS & $0.573^{\star}$ & $0.520^{\star}$ & $-0.306^{\dagger}$ & $0.316^{\dagger}$ & $-0.301^{\dagger}$ & $-0.370^{\dagger}$ & -0.172 & 0.156 & 0.103 \\
\hline Emotional exhaustion & & $0.754^{*}$ & $-0.398^{*}$ & $0.535^{*}$ & $-0.360^{\dagger}$ & $-0.445^{\star}$ & -0.443 & 0.103 & 0.224 \\
\hline Depersonalization & & & -0.240 & 0.270 & -0.175 & -0.246 & -0.186 & 0.116 & -0.038 \\
\hline Personal achievements & & & & -0.028 & 0.271 & 0.226 & 0.300 & -0.264 & -0.193 \\
\hline $\begin{array}{l}\text { Psychological } \\
\text { demands }\end{array}$ & & & & & $-0.390^{\dagger}$ & $-0.534^{*}$ & $-0.531^{*}$ & -0.198 & $0.327 \dagger$ \\
\hline Control over the job & & & & & & $0.623^{*}$ & $0.619^{*}$ & -0.049 & -0.061 \\
\hline Social support & & & & & & & $0.692^{*}$ & -0.070 & -0.060 \\
\hline Personal esteem & & & & & & & & -0.165 & -0.126 \\
\hline Double presence & & & & & & & & & 0.075 \\
\hline
\end{tabular}


Table 4. "Stepwise" multiple regression using CopSoQ-ISTAS21 dimensions as predictors and MBI dimensions as criteria $(n=42)$

\begin{tabular}{|c|c|c|c|c|c|c|}
\hline \multirow[b]{3}{*}{ Predictor } & \multirow{2}{*}{\multicolumn{2}{|c|}{$\frac{\text { Emotional exhaustion }(n=42)}{\text { Corrected } R^{2}: 0.443}$}} & \multirow{2}{*}{\multicolumn{2}{|c|}{$\frac{\text { Depersonalization }(n=42)}{\text { Corrected } R^{2}: 0.199}$}} & \multirow{2}{*}{\multicolumn{2}{|c|}{$\begin{array}{c}\text { Personal achievements }(n=42) \\
\text { Corrected } R^{2}: 0.262\end{array}$}} \\
\hline & & & & & & \\
\hline & Standardized beta $(\mathrm{Cl})$ & $\mathrm{p}$ & Standardized beta $(\mathrm{Cl})$ & $\mathrm{p}$ & Standardized beta $(\mathrm{Cl})$ & $p$ \\
\hline Psychological demands & $\begin{array}{c}0.397 \\
(0.4122 .140)\end{array}$ & 0.003 & 0.115 & 0.440 & $\begin{array}{c}0.390 \\
(0.0161 .376)\end{array}$ & 0.045 \\
\hline Control over the job & -0.084 & 0.533 & -0.020 & 0.892 & 0.090 & 0.637 \\
\hline Social support & 0.052 & 0.686 & -0.092 & 0.514 & 0.016 & 0.944 \\
\hline Insecurity & -0.090 & 0.544 & -0.058 & 0.702 & -0.232 & 0.135 \\
\hline Double presence & 0.106 & 0.396 & 0.032 & 0.823 & 0.069 & 0.674 \\
\hline Personal esteem & -0.204 & 0.156 & -0.091 & 0.520 & $0.431(0.1981 .959)$ & 0.018 \\
\hline PSS & $\begin{array}{c}0.451 \\
(0.358-1.257)\end{array}$ & 0.001 & $\begin{array}{c}0.520 \\
(0.232-0.775)\end{array}$ & 0.001 & $\begin{array}{c}-0.325 \\
(-0.610-1.376)\end{array}$ & 0.038 \\
\hline
\end{tabular}

As shown in other works, we found a relationship between stress and burnout ${ }^{25,26}$, especially with regard to EE. In addition, table 3 summarizes important correlations between stress, PDs, CJ and SS. This evidences the modulating role of stress with regard to job-associated risks, and the need for interventions that improve working conditions to be carried out.

Finally, it seems important mentioning that $38 \%$ of residents have experienced some type of aggression or threat from patients. These data confirm the worrying situation healthcare professionals are in general, and in particular, the medical group ${ }^{27,28}$. Some authors have precisely associated high levels of anxiety, emotional exhaustion, and depersonalization with physical aggressions ${ }^{29}$.

The limitations inherent to this work include its sample size and final rate of participation, which are problems that are common to most studies on this subject. A single-center study has been performed, although the characteristics of our university hospital are similar to those at the national level, and it would, therefore, be in order thinking of possible generalization of the results. In future works, it would be interesting addressing this reality in a multi-center study and continue to exploit the used constructs and other psychological dimensions able to predict burnout. The need to increase the support to residents by staff physicians is evident. Furthermore, implementation of programs for training on skills by means of which to improve the transition from undergraduate to residency is suggested, just as it is done in other countries of our area $^{30}$.

\section{Acknowledgments}

We would like to acknowledge the Hospital Clínico San Cecilio (Granada, Spain), junior doctors who have understood the importance of the study and why it was necessary.

\section{Conflict of interests}

There are no financial, working or other types of relationships that that may constitute a conflict of interests with regard to the present work.

\section{References}

1. Ministerio de Sanidad, Servicios Sociales e Igualdad. Un total de 35.320 titulados optan mañana a una de las 7.527 plazas de formación sanitaria especializada de la convocatoria 2014-2015. Madrid; 2015. (Consultado el 15 de febrero de 2015.) Disponible en: http://www.msssi.gob.es/ gabinete/notasPrensa.do?id=3541.

2. Gaceta Médica. En España hay $30.051 \mathrm{MIR}$, un $3,76 \%$ menos que el año pasado. Madrid; 2015. (Consultado el 1 de marzo de 2015.) Disponible en: http//www.gacetamedica.com; http://goo.gl/qC5XRU.

3. Gutiérrez Díez MC, Santamaría Pablos A, Delgado Diego A, Moreno Marín JA, Monasterio Rentaría AM, Landaluce Fuentes M, et al. Desgaste profesional: calidad de las relaciones interpersonales en los equipos de trabajo. Emergencias. 2008;20:73-4.

4. Moreno-Millán E. Estrés ocupacional en los profesionales de la medicina aguda. Emergencias. 2007;19:151-3.

5. Fernández-Prada M, González-Cabrera J, Torres F, Iribar-lbabe C, Peinado JM. Calidad de vida relacionada con la salud en una muestra de médicos internos residentes que realizan guardias en un servicio de urgencias: una perspectiva de género. Rev Med Chile. 2014;142: 193-8.

6. Fonseca M, Sanclemente G, Hernández C, Visiedo C, Bragulat E, Miró O. Residentes, guardias y síndrome de burnout. Rev Clin Esp. 2010;210:209-15.

7. Grau A, Flichtentrei D, Suñer R, Prats M, Braga M. Influencia de factores personales, profesionales y transnacionales en el síndrome de burnout en personal sanitario hispanoamericano y español (2007). Rev Esp Salud Publica. 2009;83:215-30.

8. Agencia Europea para la Seguridad y la Salud en el Trabajo. La semana europea para la seguridad y la salud en el trabajo. Bruselas; 2015. (Consultado el 1 de marzo de 2015.) Disponible en: https://www. 
healthy-workplaces.eu/es/; https://www.healthy-workplaces.eu/es/campaign-partners/national-focal-points.

9. González-Cabrera J, Fernández-Prada M, Molina-Ruano R, Blazquez A Guillén-Solvas J, Peinado JM. Psychosocial risk at work, self-perceived stress, and salivary cortisol level in a sample of emergency physicians in Granada. Emergencias. 2012;24:101-6.

10. Ghaddar A, Ronda E, Nolasco A, Álvares N, Mateo I. Exposure to psychosocial risks at work in prisons: does contact with inmates matter? A pilot study among prison workers in Spain. Stress Health. 2011;27:170-6.

11. Bermúdez RM, Martínez-Arquero G, Barón FJ, Hernández-Mendo A. An interdisciplinary approach to teachers' voice disorders and psychosocia working conditions. Folia Phoniatr Logop. 2010;62:24-34

12. Cohen S, Herbert TB. Health psychology: psychological factors and physical disease from the perspective of human psychoneuroimmunology. Annu Rev Psychol. 1996;47:113-42.

13. Trujillo HM, González-Cabrera J. Propiedades psicométricas de la versión española de la "Escala de estrés percibido" (EEP). Psicol Conductual. 2007;15:457-77.

14. Moncada S, Llorens $C$, Font A, Galtés F, Giné A. Exposición a riesgos psicosociales entre la población asalariada en España (2004-05): valores de referencia de las 21 dimensiones del cuestionario ISTAS21 COPSOQ. Rev Esp Salud Publica. 2008;82:667-75.

15. Gil-Monte PR, Peiró JM. Validez factorial del Maslach Burnout Inventory en una muestra multiocupacional. Psicothema. 1999;11:679-89.

16. Karasek R, Theorell, T. Healthy work. Stress, productivity, and the reconstruction of working life. New York: Basic Books; 1990.

17. Moreira JM, Álvarez, MC. Clima organizacional y estrés en una unidad de alto riesgo. Emergencias. 2002;14:6-12.

18. Sánchez M, Salgado E, Miró O. Mecanismos organizativos de adaptación y supervivencia de los servicios de urgencias. Emergencias. 2008;20:48-53

19. Peinado-Herreros JM. Definición de las competencias que debe adquiri el futuro médico. Formación de los profesores. Educ Med. 2008;11:47-51.
20. González de Dios P, Pollanco I, Díaz CA. De las facultades de medicina a la residencia de pediatría, pasando por el examen de médico interno residente: ¿algo debe cambiar? Resultados de una encuesta en residentes de pediatría de cuarto año. An Pediatr (Barc). 2009;70:467-76.

21. Llupià A, Costas L, Grau J, Trilla A. Conocimientos, capacidades e intereses de los médicos internos y residentes (MIR) al incorporarse al hospital. Med Clin (Barc). 2009:133:107-11.

22. Pérez-Ciordia I, Guillén-Grima F, Brugos A, Aguinaga Ontoso I. Satisfacción laboral y factores de mejora en profesionales de atención primaria. An Sist Sanit Navar. 2013;36:2453-62.

23. Grau-Martín A, Suñer-Soler R. Síndrome de burnout y residentes: reflexiones sobre la magnitud del fenómeno. Rev Clin Esp. 2011;211:112-3.

24. Suñer-Soler R, Grau-Martín A, Font-Mayolas S, Gras ME, Bertran C, Sullman MJ. Burnout and quality of life among Spanish healthcare personnel. J Psychiatr Ment Health Nurs. 2013;20:305-13.

25. Gelfand DV, Podnos YD, Carmichael JC, Saltzman DJ, Wilson SE Williams RA. Effect of the 80-hour workweek on resident burnout. Arch Surg. 2004;139:933-8.

26. Graham J, Potts HW, Ramirez AJ. Stress and burnout in doctors. Lancet. 2002;360:1975-6.

27. Miret C, Larrea A. El profesional en urgencias y emergencias: agresividad y burnout. An Sist Sanit Navar. 2010;33(Supl 1):193-201.

28. Martínez-Jarreta B, Gascón S, Santed MA, Goicochea J. Análisis médico-legal de las agresiones a profesionales sanitarios. Aproximación a una realidad silenciosa y a sus consecuencias para la salud. Med Clin (Barc). 2007;128:307-10.

29. Gascón S, Martínez-Jarreta B, López Verdejo MA, Diana I, López-Torres J, Castellano M. Respuestas desadaptativas al estrés derivadas de agresiones a profesionales sanitarios. Rev SEMST. 2008:3:103-5.

30. Van Hell EA, Kuks JBM, Borleffs JCC, Cohen-Schotanus J. Alternating skills training and clerkships to ease the transition from preclinical to clinical training. Med Teach. 2011;33:689-96. 